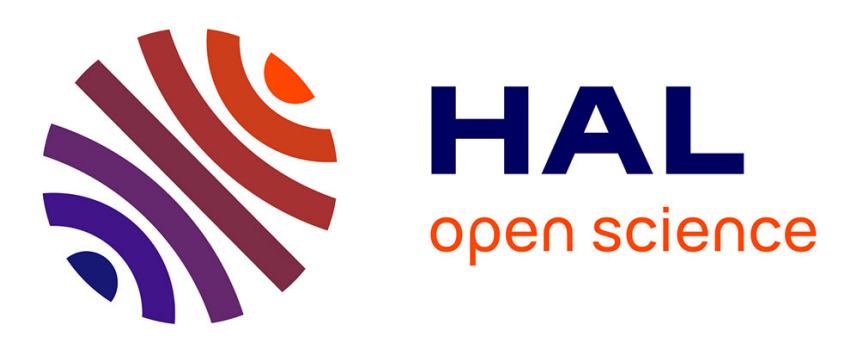

\title{
Covalent enzyme coupling on cellulose acetate membranes for glucose sensor development
}

Robert Sternberg, Dilbir S. Bindra, George S. Wilson, Daniel R. Thévenot

\section{To cite this version:}

Robert Sternberg, Dilbir S. Bindra, George S. Wilson, Daniel R. Thévenot. Covalent enzyme coupling on cellulose acetate membranes for glucose sensor development. Analytical and Bioanalytical Chemistry, 1988, 60, pp.2781-2786. 10.1021/ac00175a028 . hal-01179370

\author{
HAL Id: hal-01179370 \\ https://hal.science/hal-01179370
}

Submitted on 23 Jul 2015

HAL is a multi-disciplinary open access archive for the deposit and dissemination of scientific research documents, whether they are published or not. The documents may come from teaching and research institutions in France or abroad, or from public or private research centers.
L'archive ouverte pluridisciplinaire HAL, est destinée au dépôt et à la diffusion de documents scientifiques de niveau recherche, publiés ou non, émanant des établissements d'enseignement et de recherche français ou étrangers, des laboratoires publics ou privés. 
Reprinted from Analytical Chemistry 1988, 60, 2781.

Copyright (c) 1988 by the American Chemical Society and reprinted by permission of the copyright owner.

\title{
Covalent Enzyme Coupling on Cellulose Acetate Membranes for Glucose Sensor Development
}

\author{
Robert Sternberg, ${ }^{1}$ Dilbir S. Bindra, ${ }^{2}$ George S. Wilson, ${ }^{*, 2}$ and Daniel R. Thévenot ${ }^{*, 1}$ \\ Laboratoire de Bioélectrochimie et d'Analyse du Milieu, U.F.R. de Sciences et Technologie, Université Paris-Val de \\ Marne, Avenue du Général de Gaulle, 94010 Créteil Cedex, France, and Department of Chemistry, University of \\ Kansas, Lawrence, Kansas 66045
}

\begin{abstract}
Methods for immobilizing glucose oxidase (GOx) on cellulose acetate (CA) membranes are compared. The optimal method involves covalent coupling of bovine serum albumin (BSA) to CA membrane and a subsequent reaction of the membrane with GOx, which has previously been activated with an excess of $p$-benzoquinone. This coupling procedure is fairly reproducible and allows the preparation of thin membranes (5-20 $\mu \mathrm{m})$ showing high surface activities $\left(1-3 \mathrm{U} / \mathrm{cm}^{2}\right)$ which are stable over a period of 1-3 months. Electrochemical and radiolabeling experiments show that enzyme inactivation as a result of immobilization is negligible. A good correlation between surface activity of membranes and their GOx load is observed.
\end{abstract}

\section{INTRODUCTION}

The performance of an enzyme electrode is ultimately dependent on the ability of its enzymatic membrane to sustain

* Author to whom correspondence should be directed.

${ }^{1}$ Universitê Paris-Val de Marne.

${ }^{2}$ University of Kansas. and protect the enzyme. Among the available methods of enzyme immobilization, four methods are currently used: adsorption followed by reticulation with bifunctional reagents such as glutaraldehyde (1), covalent coupling between enzyme and activated support (2-5) or activated enzyme and support (6-8), and reversible immunological coupling (9). Those involving covalent coupling to solid supports are of great interest since they generally yield the best activity stabilities (10). Nevertheless two difficulties may be encountered: low levels of activatable or activated surface groups on the support and denaturation of enzyme if covalent coupling is accomplished through functional groups of the enzyme which are essential to its catalytic activity. Highly active and stable membranes may be prepared by acyl azide activation of reconstituted collagen films $(2,11)$. However such membranes have been found to be too thick and too fragile, especially at $37^{\circ} \mathrm{C}$, to be recommended for in vivo applications of enzyme electrodes. As cellulose acetate (CA) membranes of different thickness and permeability may easily be prepared by film casting or coating and because they exhibit significant permselectivity toward anions (12), we have studied their ability to support enzyme and be used for an in vivo implantable glucose sensor. 


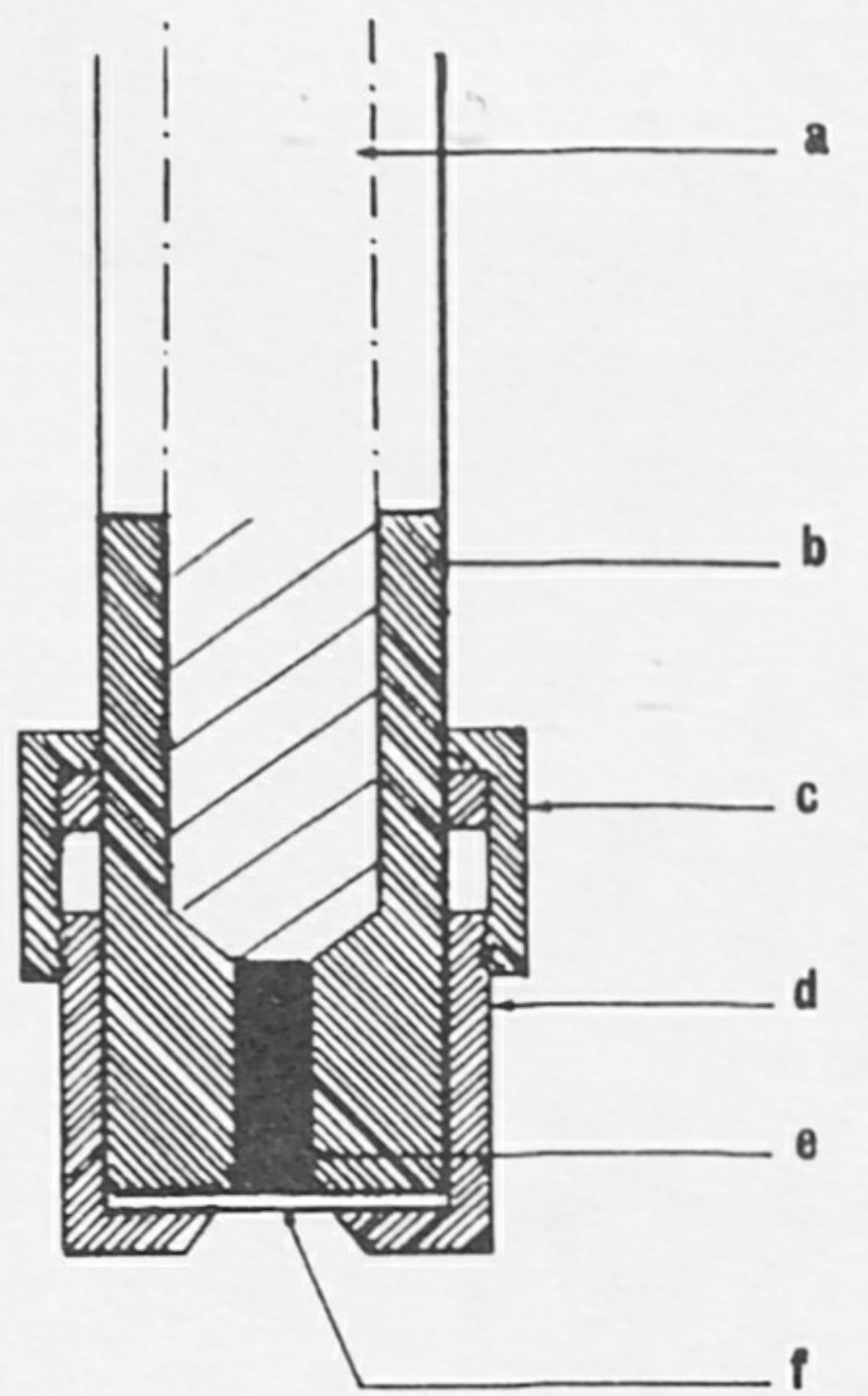

Figure 1. Schematic diagram of rotating membrane electrode: (a) rotating disk electrode shaft and electrical contact, (b) Kel-F body, (c) threaded collar, (d) membrane support cap, (e) platinum electrode, and (f) membrane.

The literature is abundant with reports of glucose sensors and many of these are used routinely for in vitro clinical determinations. Despite a history of more than 25 years (13), no completely reliable implantable sensor has yet been developed (14). For such applications a miniaturized sensor is needed and the fabrication of such devices through multilayer film deposition is a major problem. It is quite evident that miniaturized sensors will yield high sensitivity and stability only if the enzyme layer and the associated polymer layers can be deposited in a reproducible fashion. Commercially available membranes are not suitable for this purpose. The enzyme can be immobilized and protective polymer films deposited by dip coating (15). Because of the low success rate $(<40 \%)$ associated with such a technique, there exists a need for optimization of procedures for both enzyme and protective layer preparation. Starting with an intact membrane provides a defined system for the optimization process.

This paper proposes and evaluates a method of glucose oxidase $(\mathrm{GOx})$ coupling to $\mathrm{CA}$ membranes. These membranes have initially been activated and coupled to bovine serum albumin (BSA) in order to increase the number of functional groups to which GOx may be coupled and to impart a proteic environment to the enzyme. GOx is coupled to CA-BSA membranes by using $p$-benzoquinone (PBQ) as bifunctional reagent $(9,16,17)$. Use of radiolabeled GOx, in order to keep a track of enzymatic activity and investigate the reasons for the loss of sensor response with time, is also discussed. This work allows for the correct choice of coupling procedure and support before the whole glucose sensor is assembled.

\section{EXPERIMENTAL SECTION}

Instrumentation. GOx activity of membranes was determined by continuous monitoring of enzymatically generated hydrogen peroxide on a combined platinum disk electrode (anode diameter $2 \mathrm{~mm}$ ) (YSI Model 2150) covered with a general purpose cellulose acetate membrane. This electrode was connected to a YSI Model 25 Oxidase Meter (Yellow Springs Instruments, Yellow Springs, $\mathrm{OH})$ and to a potentiometric recorder (Curken). Determinations of solution and membrane radioactivity were performed on a LKB Wallac 80000 automated gamma counter. GOx membranes were mounted on a rotated platinum disk electrode (anode diameter $3 \mathrm{~mm}$ ) using a specifically designed membrane holder tip (Figure 1). The rotation speed of the membrane and anode was controlled by a Solea-Tacussel (Lyon, France) EDI motor and Controvit power unit. $\mathrm{A} \mathrm{Ag} / \mathrm{AgCl}$ reference and a platinum wire auxiliary electrode were connected, together with the platinum disk anode, to a BAS LC4A amperometric detector (Bioanalytical Systems, West Lafayette, IN) and potentiometric recorder (Curken). All experiments were performed in thermostated cells at $37^{\circ} \mathrm{C}$.
Chemicals. Reagents. Pure p-benzoquinone (PBQ) was obtained from Merck and was recrystallized from petroleum ether. Sodium borohydride from Sigma (98\%) was used and Cerium(IV) sulfate-2-(sulfuric acid) was obtained from Alfa Division (Ventron). Acetone and ethanol (both AR 100\%) were obtained from Mallinckrodt. Cellulose acetate (CA) with $39.8 \%$ acetyl content, was purchased from Aldrich Jansen Chimica. Glucose, hydrogen peroxide, and phosphate salts were reagent grade and all solutions were prepared in doubly distilled water.

Proteins. Glucose oxidase (GOx) isolated from Aspergillus niger, (grade VII, $136000 \mathrm{U} / \mathrm{g}$ ) and bovine serum albumin (BSA) fraction $\mathrm{V}$ were obtained from Sigma. Radiochemicals. $\mathrm{Na}^{125} \mathrm{I}$ $(23 \mathrm{mCi} / \mathrm{mL}$ in $0.01 \mathrm{~N} \mathrm{NaOH})$ was obtained from ICN Radiochemicals (Irvine, CA).

Glucose Oxidase Membrane Preparation. a. Cellulose Acetate Membrane Preparation. With stirring, $1.8 \mathrm{~g}$ of CA was dissolved in $15.8 \mathrm{~g}$ of acetone, and $2.8 \mathrm{~mL}$ of distilled water was added. After homogenization, this solution was cast on a glass plate and evaporated for $60 \mathrm{~s}$ at $22^{\circ} \mathrm{C}$ to form a thin membrane $(0.015 \mathrm{~mm}$ in the wet state and $0.010 \mathrm{~mm}$ in the dry state). The CA membrane was removed from the glass plate by immersing the plate in distilled water. The membrane was cut into smaller pieces and stored in distilled water.

b. Cellulose Acetate Membrane Activation. Procedure A. Four CA membranes $(2.5 \mathrm{~cm} \times 2.5 \mathrm{~cm})$ were suspended for $3 \mathrm{~h}$ in $100 \mathrm{~mL}$ of $1 \mathrm{mM} \mathrm{Ce}(\mathrm{IV})$ solution in $0.1 \mathrm{M}$ nitric acid prepared just prior to use. Then the membranes were washed in distilled water for $5 \mathrm{~min}$ and immersed in $10 \mathrm{~mL}$ of $10 \mathrm{mg} / \mathrm{mL} \mathrm{BSA}$ in $0.1 \mathrm{M}$ borate buffer, $\mathrm{pH} 9.0$. The volume of BSA solution was reduced to about $1 \mathrm{~mL}$ and three additions of $2 \mathrm{mg}$ of sodium borohydride were made every $20 \mathrm{~min}$ at room temperature. After a second washing of $5 \mathrm{~min}$ in distilled water, the membranes were stored in $0.1 \mathrm{M}$ phosphate buffered saline solution (PBS), $\mathrm{pH}$ 7.4, at room temperature until the $\mathrm{GOx}$ coupling reaction was performed.

Procedure B. This method is the same as procedure A except that a higher $\mathrm{Ce}(\mathrm{IV})$ concentration $(100 \mathrm{mM})$ and a shorter oxidation time $(20 \mathrm{~min})$ were employed.

Procedure C. In this case $100 \mathrm{~mL}$ of $100 \mathrm{mM}$ sodium periodate (20 min) was employed as oxidizing agent. The membranes were washed and BSA added as in procedure A. The Schiff base formed was reduced for $2 \mathrm{~h}$ by adding $4 \mathrm{mg}$ of sodium cyanoborohydride to the $1 \mathrm{~mL}$ of BSA solution containing the membrane.

c. Glucose Oxidase Activation. Freshly prepared PBQ solution $0.1 \mathrm{~mL}(15 \mathrm{mg}$ in $1 \mathrm{~mL}$ ethanol) was introduced in an aluminum-foil-covered tube containing $0.5 \mathrm{~mL}$ of GOx solution $(20 \mathrm{mg}$ in $0.1 \mathrm{M}$ PBS pH 7.4). After $30 \mathrm{~min}$ of incubation at $37^{\circ} \mathrm{C}$, the mixture was filtered through a G-25 Sephadex column $(1 \times 10$ $\mathrm{cm})$ coupled with a peristaltic pump $(20 \mathrm{~mL} / \mathrm{h})$ and equilibrated with $0.15 \mathrm{M}$ sodium chloride. The first fraction, a pink-brown band of 2-3 mL, was collected and used as the enzyme coupling solution.

d. Coupling Reaction. The CA-BSA membranes were suspended in $2-3 \mathrm{~mL}$ of activated GOx solution, whose $\mathrm{pH}$ was adjusted to $8.0-9.0$ with $0.25 \mathrm{~mL}$ of $1.0 \mathrm{M}$ sodium carbonate solution. After $38 \mathrm{~h}$ of incubation at room temperature, the membranes were removed, washed in stirred $0.15 \mathrm{M}$ potassium chloride solution for $24 \mathrm{~h}$ and finally stored in $0.1 \mathrm{M}$ PBS, $\mathrm{pH}$ 7.4 , containing $1.5 \mathrm{mM}$ sodium azide. The azide was added to all storage and experimental buffers to limit microbial contamination and catalase activity.

Radiolabeled Glucose Oxidase Preparation. The iodine monochloride method described by Helmkamp, Contreras, and Bale (18) was chosen to incorporate ${ }^{125} \mathrm{I}$ into GOx. A $0.5 \mathrm{mM} \mathrm{ICl}$ reagent was prepared by adding $4 \mu \mathrm{L}$ of pure $\mathrm{ICl}$ to $100 \mathrm{~mL}$ of $2 \mathrm{M} \mathrm{NaCl}$. In a $1-\mathrm{mL}$ conical vial was placed $80 \mu \mathrm{L}$ of $0.5 \mathrm{mM}$ $\mathrm{ICl}$ and the desired amount of $\mathrm{Na}^{125} \mathrm{I}$ solution. Typically, 1.0-2.5 $\mu \mathrm{Ci}$ of ${ }^{125} \mathrm{I}$ was used to iodinate $1.0 \mathrm{mg}$ of protein, depending upon the specific activity needed. The desired amount of glucose oxidase in a volume of $0.20 \mathrm{~mL}$ was added to the vessel with the room lights turned off. The contents of the vessel were mixed by tapping and allowed to react for $2 \mathrm{~min}$ in the dark. The reaction mixture was applied to the top of a G-25 Sephadex column $(25 \times 1 \mathrm{~cm})$ that had been equilibrated with PBS, $\mathrm{pH}$ 7.4. Elution was continued with $\mathrm{PBS}$ at a flow rate of $0.5 \mathrm{~mL} / \mathrm{min}$ and 1-mL fractions were collected. The effluent was monitored 
with a gamma counter and the first fraction, containing labeled protein, was collected. The pooled protein was concentrated to about $1.5 \mathrm{~mL}$ by using pressure dialysis. The ratio of proteinbound iodide to total iodide was determined by the trichloroacetic acid (TCA) precipitation method (19). The value, expressed as efficiency of labeling, was usually $95-98 \%$. The same data were used to calculate the specific activity of the iodinated glucose oxidase in microcuries of ${ }^{125} \mathrm{I}$ attached per milligram of glucose oxidase. The spectrophotometric determination of enzymatic activity of radiolabeled glucose oxidase solution showed retention of $80-85 \%$ of the original activity.

Glucose Oxidase Membrane Characterization. a. Enzymatic Surface Activity Determination. The hydrogen peroxide anodic sensor, covered with a nonenzymatic CA membrane, was immersed into a thermostated cell $\left(37^{\circ} \mathrm{C}\right)$ containing $10 \mathrm{~mL}$ of PBS. When the background current was stabilized, i.e. after 10 min of polarization, $0.1 \mathrm{~mL}$ of $1 \mathrm{M}$ glucose standard solution was added to the buffer solution. The incremental production of hydrogen peroxide was measured by placing the CA-BSAPBQ-GOx membrane in the stirred buffer solution arid then removing it. This process was repeated several times. The resulting increase in current, after suitable calibration with hydrogen peroxide standards, could be used to estimate the membrane surface enzymatic activity.

b. Sensor Response. The rotating membrane electrode was dipped into a thermostated cell at $37^{\circ} \mathrm{C}$ containing $25 \mathrm{~mL}$ of PBS. When the background current was stabilized, i.e. after about 20 min of polarization, several $0.025-0.125 \mathrm{~mL}$ additions of $1 \mathrm{M}$ glucose standard solution were performed until a $15-20 \mathrm{mM}$ final concentration was obtained. Then one or two $25-\mu \mathrm{L}$ aliquots of $0.1 \mathrm{M}$ hydrogen peroxide were added to the buffer solution. Response was calculated by comparing steady-state current either to the background current $\left(I_{\mathrm{b}}\right)$ prior to any glucose addition or to the steady-state current corresponding to the previous addition. Thus either $I-I_{\mathrm{b}}$ vs $C$ or $\Delta I / \Delta C$ vs $C$ or $\log C$ curves were plotted.

c. Immobilized Enzyme Determination. The mass of immobilized GOx was estimated from the $\gamma$ activity of the membranes prepared by using radiolabeled GOx and the specific activity of radiolabeled enzyme solution. With the initial enzyme activity of lyophilized powder (U/g) and a 15-20\% decrease of this activity due to the radiolabeling procedure taken into account, a further estimation of membrane activity expressed in $\mathrm{U} / \mathrm{cm}^{2}$ was accomplished.

\section{RESULTS AND DISCUSSION}

The purpose of this work was to find a suitable method that allows the efficient and reproducible coupling of GOx to a support suitable for an in vivo glucose sensor. We were particularly concerned with the methods and support materials that could easily be adaptable to the preparation of needle-type microsensors. Thus all commercially available solid membranes were avoided and we restricted ourselves to cast CA films as support material.

Cellulose Acetate Membrane Activation. Bovine serum albumin (BSA) $(1,3,6,7)$, gelatin $(20)$, or collagen $(2,8)$ are frequently used in enzyme immobilization techniques (21). They bring to the enzyme a proteic environment which seems favorable for its stability (11). As CA membranes usually possess low levels of accessible hydroxyl groups for covalent enzyme coupling, we have decided to increase the number of reacting groups by first covalently coupling BSA to CA (Figure 2). BSA contains more than 57 active amino groups per molecule and may be covalently grafted onto the free aldehyde groups obtained by CA hydroxyl group oxidation (Figure 3). The imine functions are subsequently reduced with borohydride. We have compared three different procedures for CA membrane activation and CA-BSA membranes from each procedure which were reacted with identical activated GOx solutions (vide supra). Comparisons of the properties of GOx membranes prepared by these three procedures (Table I) show that the best activities are obtained with procedure C, i.e. periodate oxidation followed by cyanoborohydride reduction. The use of cyanoborohydride, which is a milder reducing agent
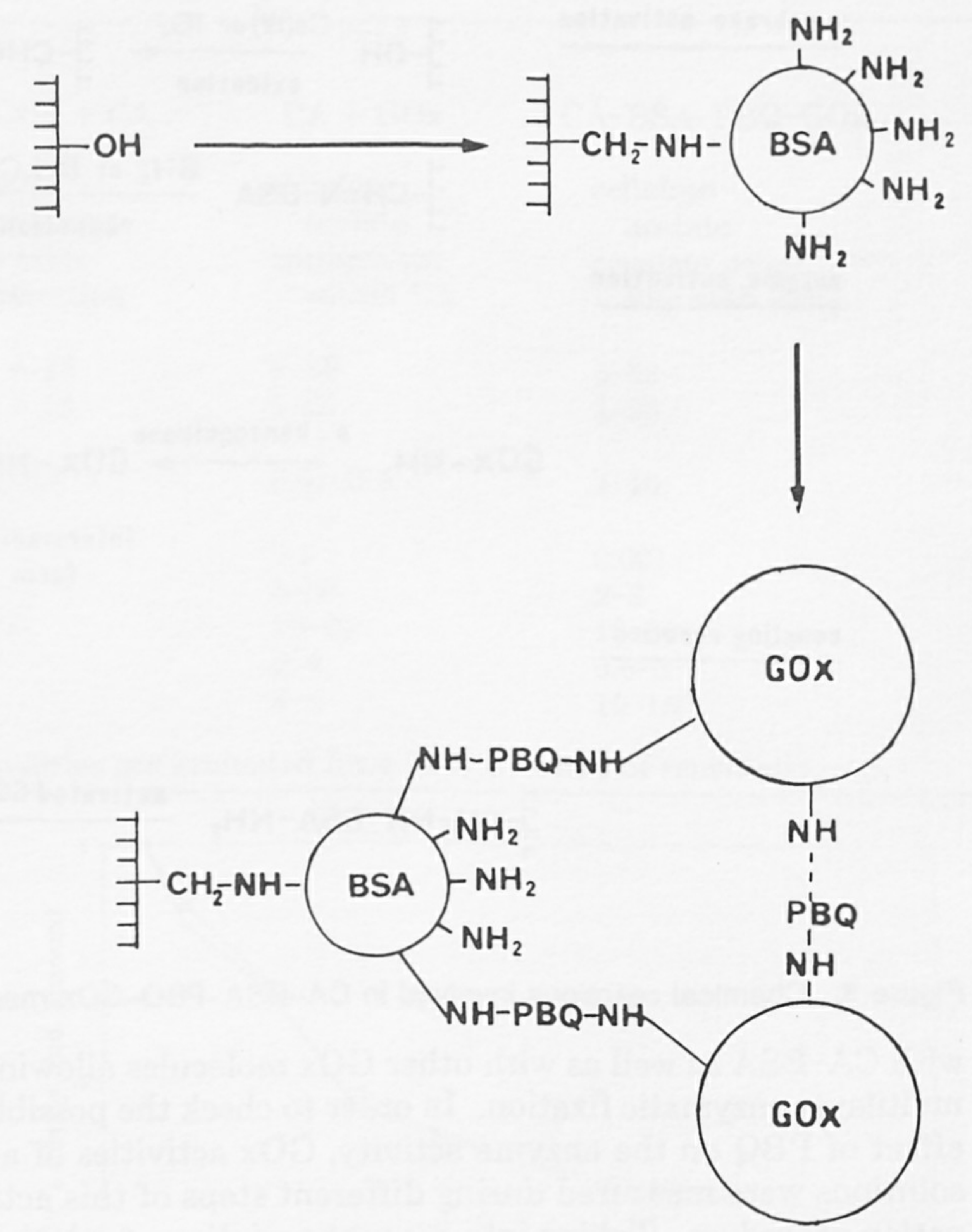

Figure 2. General scheme of GOx coupling on CA membranes: enhancement of CA surface groups by covalent BSA coupling.

\begin{tabular}{|c|c|c|c|}
\hline \multirow[t]{2}{*}{ 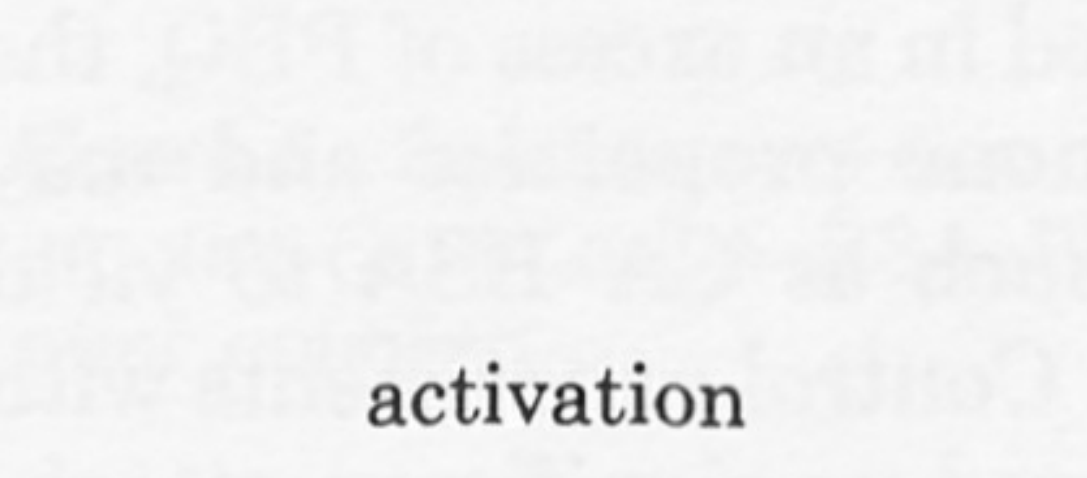 } & \multicolumn{3}{|c|}{$\begin{array}{c}\mathrm{CA}-\mathrm{BSA}-\mathrm{PBQ}-\mathrm{GOx} \text { membrane } \\
\text { preparation }\end{array}$} \\
\hline & $\begin{array}{c}\text { procedure } \\
\text { a }\end{array}$ & $\begin{array}{l}\text { procedure } \\
\mathrm{b}\end{array}$ & $\begin{array}{l}\text { procedure } \\
\text { c }\end{array}$ \\
\hline $\begin{array}{l}\text { CA membrane oxidation } \\
\text { reactant }\end{array}$ & $\mathrm{Ce}(\mathrm{IV})$ & $\mathrm{Ce}(\mathrm{IV})$ & $\mathrm{IO}_{4}^{-}$ \\
\hline concentration & 1 & 100 & 100 \\
\hline $\begin{array}{l}\text { duration (min) } \\
\text { reaction with BSA }\end{array}$ & 180 & 20 & 20 \\
\hline $\begin{array}{l}\text { concentration }(\mathrm{g} / \mathrm{L}) \\
\text { reduction }\end{array}$ & 10 & 10 & 10 \\
\hline reactant & $\mathrm{BH}_{4}^{-}$ & $\mathrm{BH}_{4}^{-}$ & $\mathrm{BH}_{3} \mathrm{CN}^{-}$ \\
\hline concentration $(\mathrm{g} / \mathrm{L})$ & $3 \times 2$ & $3 \times 2$ & 4 \\
\hline $\begin{array}{l}\text { duration (min) } \\
\text { radiolabeled } \mathrm{GOx} \text { attached }\end{array}$ & $3 \times 20$ & $3 \times 20$ & 120 \\
\hline$\left(\mu \mathrm{g} \cdot \mathrm{cm}^{-2}\right)$ & $\begin{array}{l}3.8 \pm 1.5 \\
\quad(n=3)\end{array}$ & $\begin{array}{l}8.0 \pm 2.8 \\
\quad(n=5)\end{array}$ & $\begin{array}{l}13 \pm 1.8 \\
\quad(n=5)\end{array}$ \\
\hline $\begin{array}{l}\text { GOx surface activity } \\
\left(\mathrm{U} \cdot \mathrm{cm}^{-2}\right)\end{array}$ & $\begin{array}{c}0.50 \pm 0.10 \\
(n=3)\end{array}$ & $\begin{array}{c}1.0 \pm 0.40 \\
(n=5)\end{array}$ & $\begin{array}{r}2.8 \pm 0.40 \\
(n=5)\end{array}$ \\
\hline
\end{tabular}

${ }^{a}$ Amounts of $\mathrm{GOx}$ and activities are expressed as mean \pm standard deviation for a set of membranes prepared identically. All GOx masses and activities are referred to membrane surface, i.e. $0.8 \mathrm{~cm}^{2}$.

than borohydride (procedure A and B), probably prevents breaking of disulfide bonds of the BSA protein.

Glucose Oxidase Activation and Coupling. Following a procedure described by Avrameas et al. (16), we used $p$ benzoquinone (PBQ) for activating GOx solutions. GOx was treated with an excess of $P B Q$, reagent known to react with proteins (17), and the excess PBQ was separated by size exclusion chromatography (Figure 3). Most of the above-mentioned coupling reactions take place at low temperature, low ionic strength, and within the physiological $\mathrm{pH}$ range. The reason for treating $\mathrm{GOx}$ and not the amino groups of the CA-BSA support with PBQ is that it allows GOx-PBQ to react 


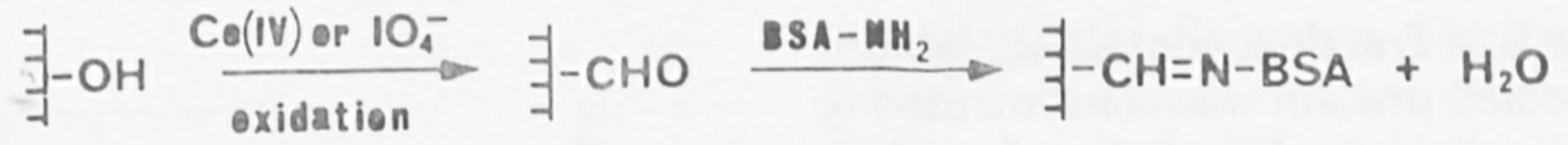

$$
\begin{aligned}
& \exists-\mathrm{CH}=\mathrm{N}-\mathrm{BSA} \underset{\text { reduction }}{\stackrel{\mathrm{BH}_{4}^{-} \text {or } \mathrm{BH}_{3} \mathrm{CN}^{-}}{\longrightarrow}} \mathrm{J}-\mathrm{CH}_{2} \mathrm{NH}-\mathrm{BSA}-\mathrm{NH}_{2}
\end{aligned}
$$

enzyme activation

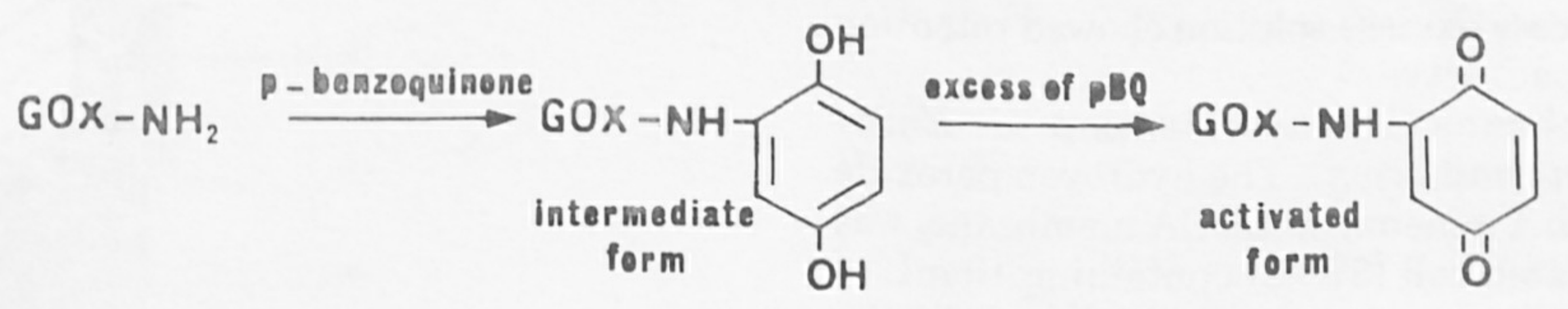

coupling reaction

separation of excess of plBQ (sephadex 625)

$$
\exists-\mathrm{CH}_{2} \mathrm{NH}-\mathrm{BSA}-\mathrm{NH}_{2} \stackrel{\text { activated } \mathrm{GOx}}{\longrightarrow} \mathrm{\exists}-\mathrm{CH}_{2}-\mathrm{NH}-\mathrm{BSA}-\mathrm{NH}
$$

Flgure 3. Chemical reactions involved in CA-BSA-PBQ-GOx membrane preparation.

with CA-BSA as well as with other GOx molecules allowing multilayer enzymatic fixation. In order to check the possible effect of PBQ on the enzyme activity, GOx activities of all solutions were measured during different steps of this activation procedure. Taking into account variation of solution volumes, spectrophotometric and electrochemical determination of GOx activities in $0.1 \mathrm{M}$ glucose solutions showed that GOx-PBQ solutions yield $92-97 \%$ initial activity. This result indicates that no significant reduction of GOx activity is occurring during this activation procedure. As reaction between GOx and $P B Q$ is performed in an excess of $P B Q$, the $\mathrm{GO} x-\mathrm{PBQ}$ product exhibits quinone properties and may continue to react with proteins such as CA-BSA to yield CA-BSA-PBQ-GOx membranes. Control experiments with nonactivated CA membranes showed no significant attachment of the enzyme.

Characteristics of Glucose Oxidase Membranes Used for Glucose Sensors. The characterization of the enzymatic membranes is important for the evaluation of various enzyme attachment procedures. We used three different approaches for such a characterization: (a) membrane surface activity, determination using continuous electrochemical monitoring of hydrogen peroxide in a stirred $0.1 \mathrm{M}$ glucose solution; (b) mounting the membrane on a rotating disk electrode tip (Figure 1), for well-defined hydrodynamics, and determination of sensor calibration curve to glucose; (c) incorporation of a radiolabel in GOx and determination of the mass of GOx in solution or on the membrane.

The first method is simple and rapid but not very accurate since hydrodynamic conditions are not well defined when membranes are freely stirred in the measuring cell. The second method is more accurate but takes into account membrane permeability to substrates and reaction products; furthermore a good contact between these thin membranes and the platinum disk is not trivial. Finally, the third method is definitely the most complicated because it requires ${ }^{125} \mathrm{I}-\mathrm{GOx}$ preparation and characterization, but it is also the most accurate and sensitive. Figure 4 shows the correlation between enzymatic activity, as monitored by surface activity, and the mass of immobilized enzyme. The mass of enzyme on the membrane of different membranes was controlled such that the amount of enzyme immobilized could be varied. All these data obtained just after coupling show an excellent correlation between surface activity and the mass of GOx immobilized. Furthermore when enzyme activities of these membranes,

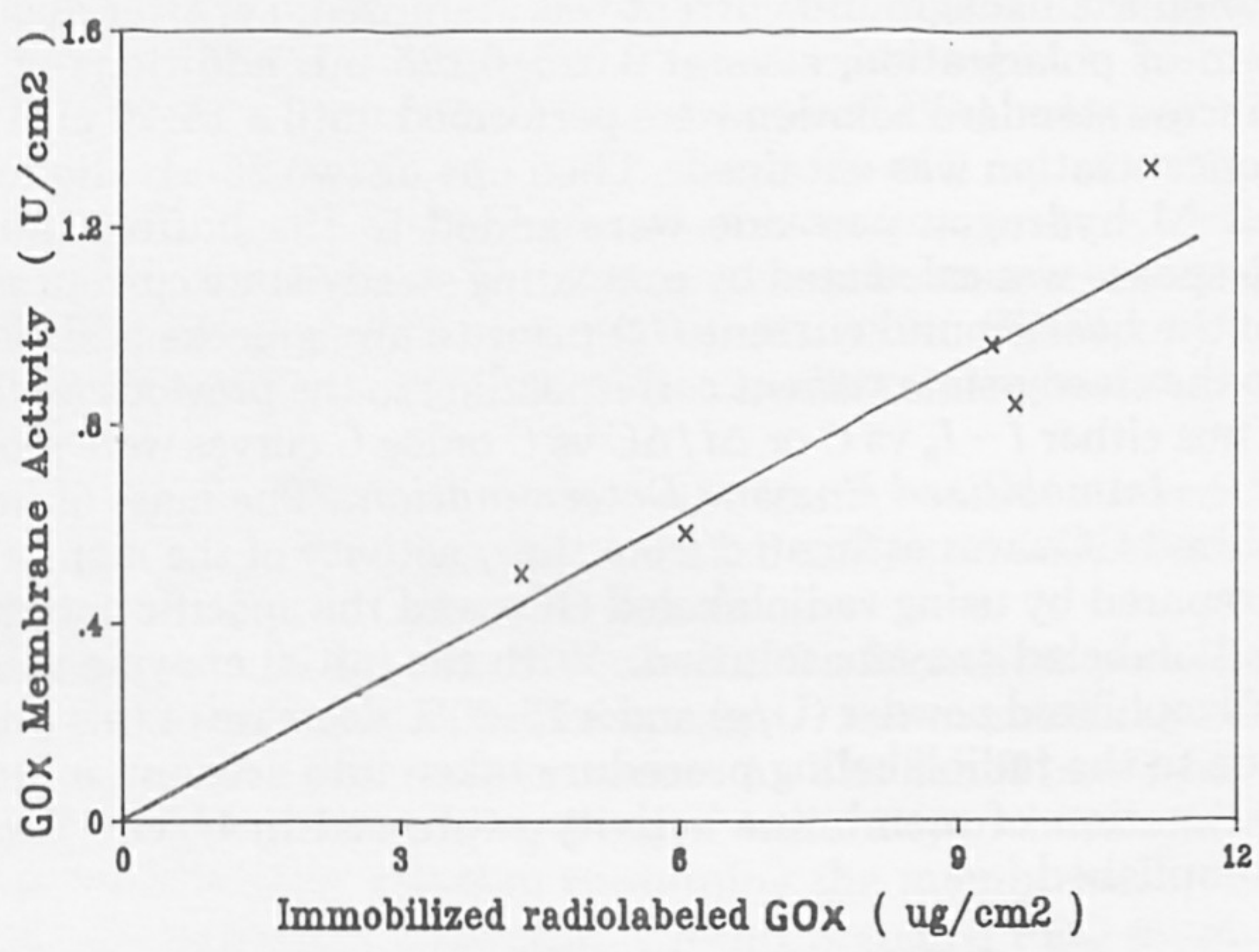

Figure 4. Correlation of GOx surface activities with immobilized ${ }^{125} \mathrm{I}-\mathrm{GOx}$ amount in different CA-BSA-PBQ-GOx membranes.

estimated from the amount of GOx immobilized, and the specific activity of the initial lyophilized GOx powder, were compared to experimental activity values, an excellent correlation was obtained. In fact the measured/calculated activity ratio was equal to $0.84 \pm 0.29$ for six membranes and 22 experiments indicating that the radiolabeling procedure allows a good evaluation not only of total GOx mass but also of its enzymatic activity.

Several experiments involving the use of radiolabeled GOx were carried out in order to understand the reasons for the loss of enzymatic activity with time, a phenomenon observed for most membranes prepared. Figure 5 compares the time-dependent loss of enzymatic activity with the loss of enzyme mass from the membrane surface. For the first 7 days, the removal of enzyme from the membrane is directly reflected in the loss of biological activity. After this time, however, the biological activity decays much more rapidly. It was surmised that this latter phenomenon was due to time dependent denaturation of the immobilized enzyme resulting from multiple covalent attachment. It is possible for the activated groups on the membrane surface to react with protein amine functions even after the coupling reaction is supposedly terminated. Such further BSA-GOx or GOx-GOx coupling may modify the enzyme configuration and produce some denaturation. To prevent this from occurring, $1 \mathrm{M}$ lysine was reacted with membranes for $6 \mathrm{~h}$ immediately after coupling. The purpose of this procedure is to deactivate remaining groups on the 
Table II. Pertinent Parameters for GOx Membranes

\begin{tabular}{|c|c|c|c|c|}
\hline parameters & collagen-GOx & $\mathrm{Col}-\mathrm{GOx}+\mathrm{CA}$ & $\mathrm{CA}+\mathrm{GOx}$ & CA-BSA-PBQ-GOx \\
\hline $\begin{array}{l}\text { membrane } \\
\text { material } \\
\text { attachment } \\
\text { procedure } \\
\text { membrane thickness }(\mu \mathrm{m})\end{array}$ & $\begin{array}{l}\text { reconstituted } \\
\text { collagen } \\
\text { acyl azide } \\
\text { activation }\end{array}$ & $\begin{array}{l}\text { collagen }+ \\
\text { cel acetate } \\
\text { acyl azide } \\
\text { activation }\end{array}$ & $\begin{array}{l}\text { cellulose } \\
\text { acetate } \\
\text { entrapment } \\
\text { within CA }\end{array}$ & $\begin{array}{l}\text { cellulose } \\
\text { acetate } \\
\text { covalent coup- } \\
\text { ling with PBQ }\end{array}$ \\
\hline $\begin{array}{l}\text { dry } \\
\text { swollen }\end{array}$ & $\begin{array}{l}100 \\
200-400\end{array}$ & $\begin{array}{l}100+15 \\
300+15\end{array}$ & $\begin{array}{l}5-25 \\
5-25\end{array}$ & $\begin{array}{l}5-25 \\
5-25\end{array}$ \\
\hline $\begin{array}{l}\text { glucose responses: } \\
\text { sensitivity }\left(\mathrm{mA} \cdot \mathrm{M}^{-1} \cdot \mathrm{cm}^{-2}\right) \\
\text { linear range }(\mathrm{mM})\end{array}$ & $8-10$ & $0.01-0.1$ & $0.01-0.1$ & $4-10$ \\
\hline $\begin{array}{l}\text { lower limit } \\
\text { upper limit } \\
\text { response time transient (s) } \\
\text { steady state (min) } \\
\text { stability } \text { (days) }\end{array}$ & $\begin{array}{l}0.001 \\
2-3 \\
20-50 \\
2-4 \\
120-2000\end{array}$ & $\begin{array}{l}0.1 \\
40 \\
50-90 \\
3-6\end{array}$ & $\begin{array}{l}0.1 \\
5-30 \\
10-60 \\
2-4 \\
4-8\end{array}$ & $\begin{array}{l}0.001 \\
2-3 \\
10-60 \\
0.5-3 \\
10-150\end{array}$ \\
\hline
\end{tabular}

${ }^{a}$ All sensor sensitivities are referred to anode area, i.e. $7.06 \mathrm{~mm}^{2} .{ }^{b}$ Stabilities are evaluated for a $50 \%$ decrease of sensitivity.

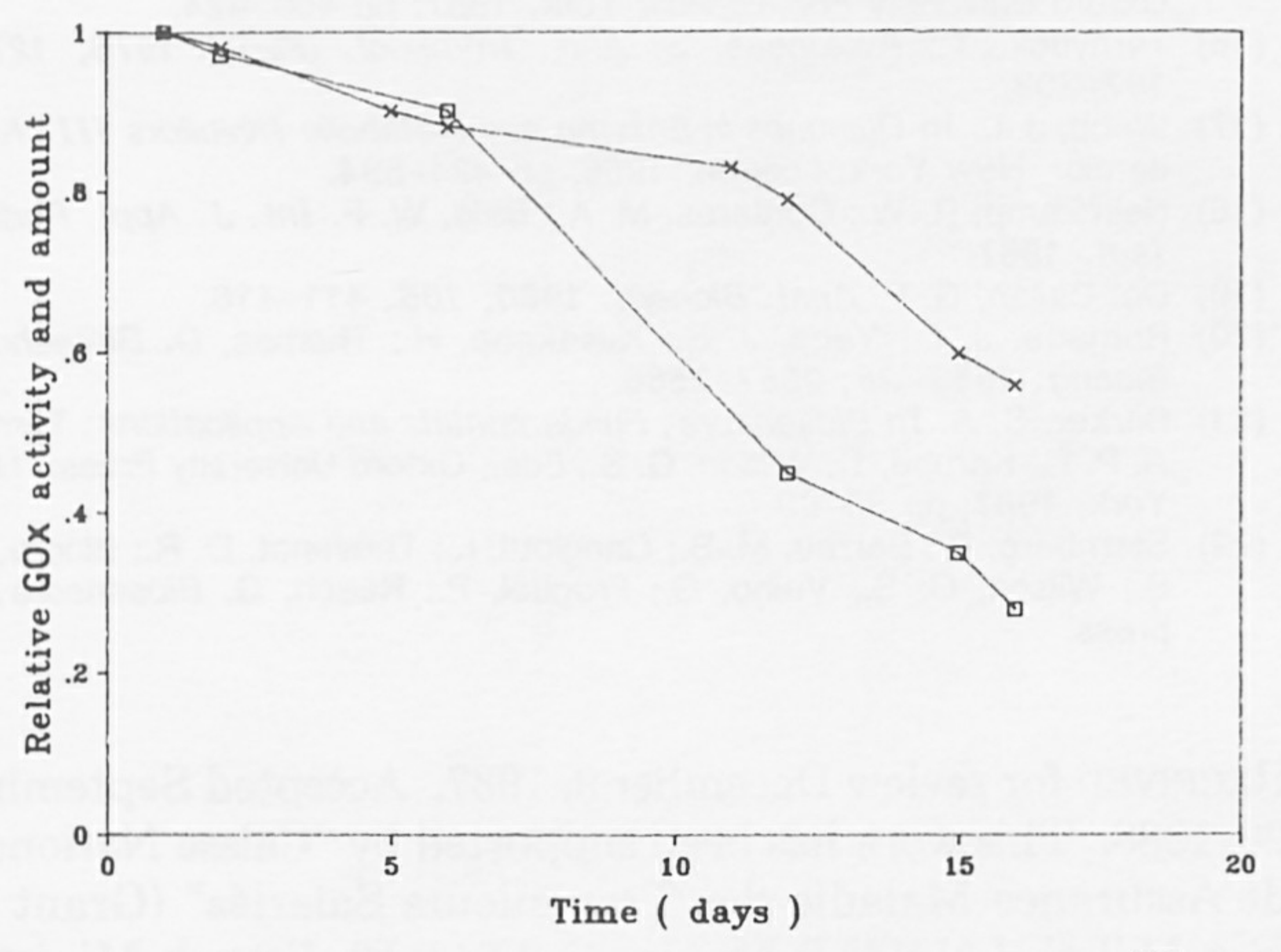

Figure 5. Relative evolution of surface GOx activity $(\mathrm{O})$ and ${ }^{125} \mathrm{I}-\mathrm{GO} x$ $(X)$ in a CA-BSA-PBQ-GOx membrane not treated with lysine after coupling.

membrane, thus preventing further coupling. The effect of this treatment is shown in Figure 6 where it will be noted that the enzymatic activity tracks the mass of immobilized protein. Protein is still lost from the membrane at an approximately comparable rate. However, in the absence of radiochemical measurements, membranes showed significant improvement on these stability values, probably because of decreased handling. A relative activity value as high as $80-85 \%$ was frequently observed after passage of $2-3$ weeks (Figure 7). As the membranes were very fragile and unsupported, handling them on a routine basis must have caused their partial disintegration. These results demonstrate that enzyme inactivation is negligible after coupling and that any slight surface activity decrease, when observed, is probably related to immobilized enzyme loss from the membrane.

Microbial degradation as a possible explanation for the observed behavior was ruled out on the basis that azide was present as an inhibitor in all storage buffers. The fact that no significant release $(<1 \%)$ of iodide was observed, as confirmed by the repetitive TCA assays (16) on stored iodinated enzyme solution also supports this belief.

Table II presents pertinent analytical parameters for GOx membranes when mounted on a platinum anode. The sensor sensitivities, as referred to anode area, of the CA-BSAPBQ-GOx membranes are very close to those for highly active acyl azide activated collagen membranes (2). As CA membranes are significantly thinner than reconstituted collagen, especially when the latter are swollen, both transient and steady-state response times for them are correspondingly much shorter. The stability at $37^{\circ} \mathrm{C}$ and anion permselectivity of CA membranes are also preferable to those of collagen for

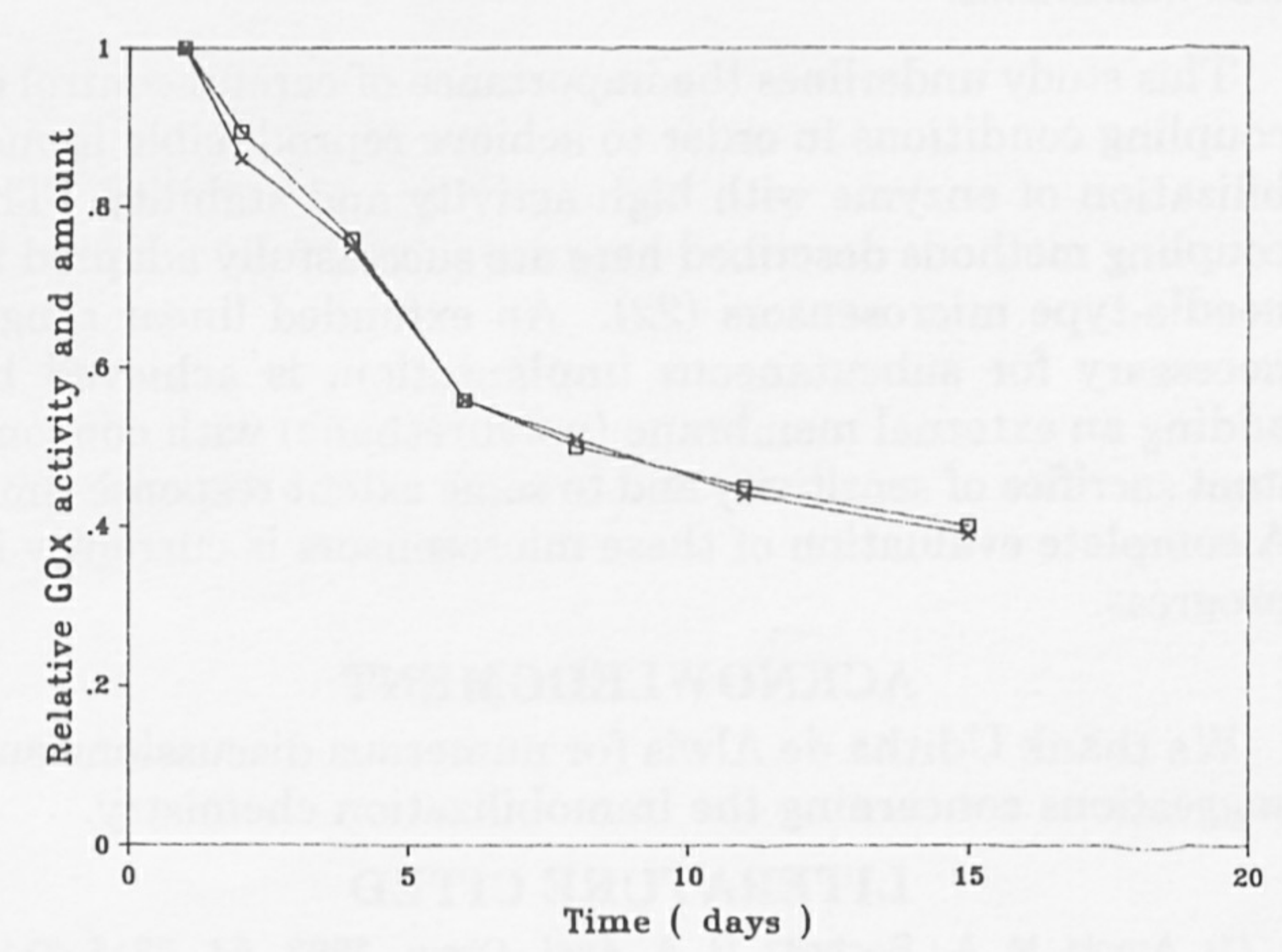

Figure 6. Relative evolution of surface GOx activity $(\mathrm{O})$ and ${ }^{125} \mathrm{I}-\mathrm{GOx}$ amount $(X)$ in a CA-BSA-PBQ-GOx membrane treated with lysine after coupling.

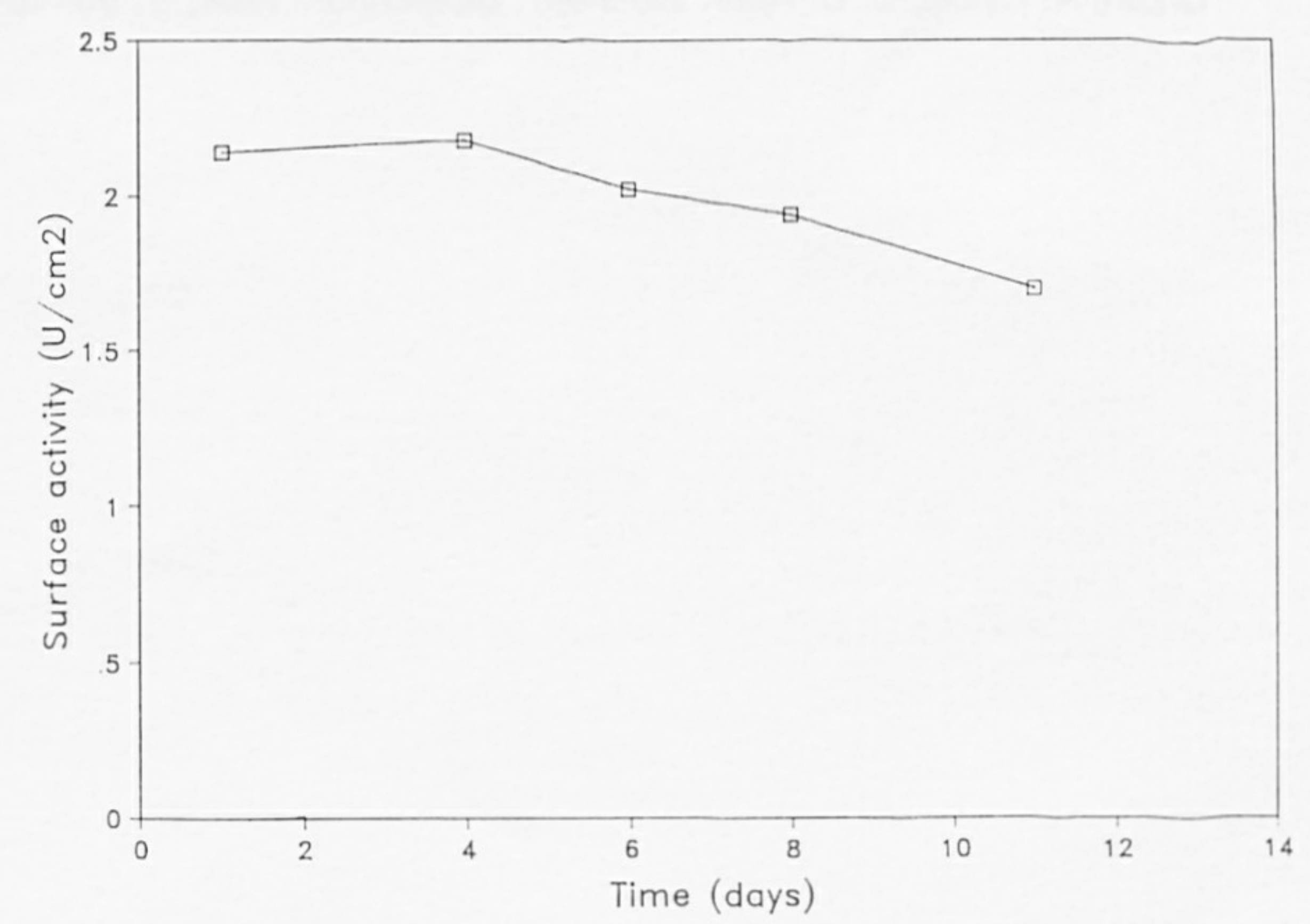

Figure 7. Evolution of surface GOx activity in a CA-BSA-PBQ-GOx membrane treated with lysine after coupling and not routinely handled for radiochemical measurements.

development of in vivo glucose sensors.

Figure 8 presents calibration curves of sensors prepared with such membranes. The linear ranges usually reach $2-3 \mathrm{mM}$ glucose for such active collagen-GOx or CA-BSA-PBQ-GOx membranes indicating that, for higher glucose concentrations, the enzymatic reaction is the rate-limiting step. High linear ranges have been obtained either with less active CA membranes using a GOx entrapment procedure or with collagenGOx membranes covered with nonenzymatic CA membranes allowing external diffusion restriction (see Table II). Indeed linear ranges as high as $15 \mathrm{mM}$ are needed for potentially implantable glucose sensors (14). 


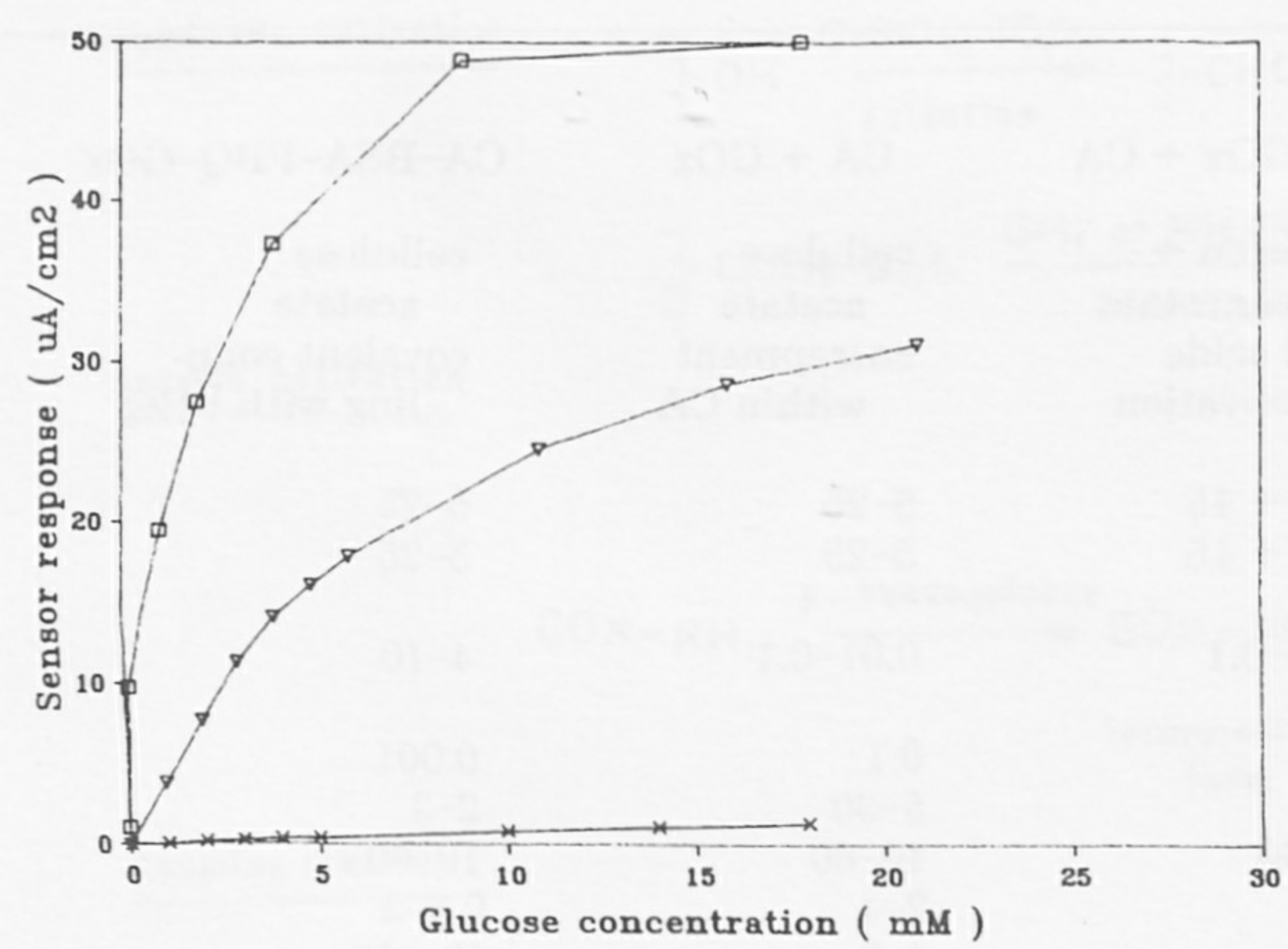

Figure 8. Glucose calibration curves of sensors prepared with (O) collagen-GOx, $(X) \mathrm{CA}$ with entrapped GOx, and $(\Delta)$ CA-BSA-PBQGOx membranes.

This study underlines the importance of careful control of coupling conditions in order to achieve reproducible immobilization of enzyme with high activity and stability. The coupling methods described here are successfully adapted to needle-type microsensors (22). An extended linear range, necessary for subcutaneous implantation, is achieved by adding an external membrane (polyurethane) with concomitant sacrifice of sensitivity and to some extent response time. A complete evaluation of these microsensors is currently in progress.

\section{ACKNOWLEDGMENT}

We thank Uditha de Alwis for numerous discussions and suggestions concerning the immobilization chemistry.

\section{LITERATURE CITED}

(1) Arnold, M. A.; Rechnitz, G. A. Anal. Chem. 1982, 54, 2315-2317.

(2) Thêvenot, D. R.; Coulet, P. R.; Sternberg, R.; Gautheron, D. C. Anal. Chem. 1979, 51, 96-100.

(3) Wingard, L. B., Jr.; Castner, J. F.; Yao, S. J.; Wolfson, S. K., Jr.; Drash, A. L.; Liu, C. C. Appl. Biochem. Biotechnol. 1984, 9, 95-104.
(4) Moody, G. J.; Sanghera, G. S.; Thomas, J. D. R. Analyst (London) 1986, 111, 605-609.

(5) Moody, G. J.; Sanghera, G. S.; Thomas, J. D. R. Analyst (London) $1986,111,1235-1238$

(6) Kulys, J. J.; Gureviciene, V. V.; Laurinavicius, V. A.; Jonuska, A. V. Biosensors 1986, 2, 35-44

(7) Mullen, W. H.; Keedy, F. H.; Churchouse, S. J.; Vadgama, P. M. Anal. Chim. Acta 1986, 183, 59-66.

(8) Mascini, M.; Mateescu, M. A.; Pilloton, R. Bioelectrochem. Bioenerg. $1986,16,149-157$.

(9) De Alwis, W. U.; Hill, B. S.; Meiklejohn, B. I.; Wilson, G. S. Anal Chem. 1987, 59, 2688-2691.

(10) Thévenot, D. R. Diabetes Care 1982, 5(3), 184-189.

(11) Thévenot, D. R.; Sternberg, R.; Coulet, P. R. Diabetes Care 1982. 5(3), 203-206.

(12) Sittampalam, G.; Wilson, G. S. Anal. Chem. 1983, 55, 1608-1610.

(13) Scheller, F. W.; Pfeiffer, D.; Schubert, F.; Renneberg, R.; Kirstein, D. In Biosensors: Fundamentals and Applications; Turner, A. P. F., Karube, I., Wilson, G. S., Eds.: Oxford University Press: New York, 1987; pp 315-346.

(14) Velho, G.; Reach, G.; Thévenot, D. R. In Biosensors: Fundamentals and Applications; Turner, A. P. F., Karube, I., Wilson, G. S., Eds.; Oxford University Press: New York, 1987; pp 390-408.

(15) Shichiri, M.: Kawamori, R.: Yamasaki, Y. In Biosensors: Fundamentals and Applications; Turner, A. P. F., Karube, I., Wilson, G. S., Eds. Oxford University Press: New York, 1987; pp 409-424.

(16) Ternynck, T.; Avrameas, S. Ann. Immunol. (Paris) 1976, 127C, 197-208.

(17) Webb, J. L. In Quinones in Enzyme and Metabolic Inhibitors III; Academic: New York, London, 1966; pp 421-594.

(18) Helmkamp, R. W.; Conteras, M. A.; Bale, W. F. Int . J. Appl. Radiat. Isot. 1967

(19) Der-Balian, G. P. Anal. Bichem. 1980, 106, 411-416.

(20) Romette, J. L.; Yang, J. S.; Kusakabe, H.; Thomas, D. Biotechnol. Bioeng. 1983, 25, 2557-2566.

(21) Barker, S. A. In Biosensors, Fundamentals and Applications; Turner, A. P. F., Karube, I., Wilson, G. S., Eds.; Oxford University Press: New York, 1987; pp 85-99.

(22) Sternberg, R.; Barrau, M.-B.; Gangiotti, L.; Thêvenot, D. R.; Bindra, D. S.; Wilson, G. S.; Velho, G.; Froguel, P.; Reach, G. Biosensors, in press.

RECEIVED for review December 9, 1987. Accepted September 26, 1988. This work has been supported by "Caisse Nationale de'Assurance Maladie des Travailleurs Salariês" (Grant C. N.A.M.T.S.-I.N.S.E.R.M. No. 85.3.54.8.E), French Ministry of Foreign Affairs, National Institutes of Health (U.S.) (Grant DK 30718) and "Aide aux Jeunes Diabétiques". Their financial help is gratefully acknowledged. 